\title{
Language Learning Strategies of Two Indonesian Young Learners in the USA
}

\author{
Suhendra Yusuf ${ }^{1}$ \\ 1 English Department \& Graduate School of Educational Management, Nusantara Islamic University, \\ Bandung, Indonesia \\ Correspondence: Suhendra Yusuf, English Department \& Graduate School of Educational Management, \\ Nusantara Islamic University, Jln. Soekarno-Hatta 530 Bandung, Indonesia. E-mail: \\ suhendrayusuf@gmail.com
}

Received: June 6, 2012 Accepted: June 22, 2012 Online Published: July 10, 2012

doi:10.5539/ijel.v2n4p65 URL: http://dx.doi.org/10.5539/ijel.v2n4p65

\begin{abstract}
This study attempts to discuss the English language used by Indonesian young learners who come to the US and identify their language learning strategies. Some theoretical issues in second language acquisition related to this topic are discussed and then followed by the discussion on the subjects' learning strategies and some factors related to the strategies, and the description of the subjects' language development. The two subjects are good English learners: they had "three variables" of good language learning: aptitude, motivation, and opportunity. They were bright children and they knew how to use their knowledge in learning a "new" language; they were good guessers and risk takers. They were also integratively motivated: they practiced their English; they were expressive and eager to communicate; and finally they had now a good opportunity to learn English in its natural setting. The main implication of this study is on the teaching of English to the Indonesian speakers. It is obvious that the differences between English and Indonesian sentence structures have created difficulties to the learners. A teaching syllabus based on contrastive analysis will be more realistic though only in obvious contrasting features. It should reinforce marked differences in L2, where L1 and Universal Grammar are unmarked - so as to raise learner's awareness of the new features.
\end{abstract}

Keywords: interlanguage, language learning strategy, contrastive analysis

\section{Introduction}

It is always amazing to see how children acquire a certain language in a relatively short time; not only how they produce sounds and combine them into thousands of words, but also how they construct those words into sentences to express their feelings and thoughts. It is more amazing to notice that all children in all cultures are also excellent second language learners; regardless of what languages they learn. Their cerebral plasticities - flexibilities in their neurological organizations within the critical periods for language acquisition - have made the mastery of those languages possible.

The languages used by Gina and Nadia - two Javanese girls who came to the United States accompanying their parents - are also very interesting. Gina (8:6) and Nadia (7:2) speak Javanese, their mother tongue, and Indonesian, their national language and the language of instruction in public schools in Indonesia alternately and with ease. In addition, their parents said that they also learnt Arabic for almost a year, and took a special English class for three months before they left their country. When they enrolled in elementary school in Athens, Ohio, USA, they had a new experience: they had to speak English when they were at school and had to spend eight hours a day with their American teachers and classmates.

This study attempts to discuss the English language used by the two children and identify their language learning strategies. First of all, some theoretical issues in second language acquisition related to this topic are discussed briefly, and then the method of this study is described succinctly. This section is followed by the discussions on the subjects' learning strategies and some factors related to the strategies, and the description of the subjects' language development. Finally, a conclusion and some practical implications are discussed. 


\section{The Issues}

The notion "interlanguage" was first launched by Selinker in 1969 (Selinker, 1972; 1992). It refers to "... the systematic knowledge of a second language which is independent of both the learner's first language and the target language" (Ellis, 1985: 299). Different researchers used different terms to refer to this notion: Nemser (1971) used the term "approximate system" and Corder (1971) "idiosyncratic dialects" and "transitional competence" (Ellis, 1985: 47), and then "language-learner language" (Corder, 1978). According to Ellis, this term refers to three different concepts:

(1) to the series of interlocking systems that have been the characteristics of second language acquisition;

(2) to the system of a single stage of a language development; and

(3) to the combination of a particular native language/target language, e.g. French native language/English target language versus German native language/English target language.

In this study, the term "interlanguage" refers more to the second notion, i.e., to a certain stage of second language acquisition.

Selinker (1972) as quoted by Ellis (1985: 48) suggested five principal processes operating in interlanguage:

(1) language transfer or interference;

(2) overgeneralization of target language rules;

(3) transfer of training as a result of language instructions;

(4) strategies of learning; and

(5) strategies of communication.

Through those five processes, the learners internalize the second language systems.

This stage of language development is very much influenced by the learners' language learning strategies, i.e., “... how learners accumulate new L2 rules and how they automatize existing ones" (Ellis, 1985: 299). Oxford (1990) defines language learning strategies as "... specific actions taken by the learner to make learning easier, faster, more enjoyable, more self-directed, and more transferable to new situation." Griffiths and Parr (2001) explored several approaches to learning strategies; however, the most frequent strategies used by the students were memory strategies, followed by cognitive, social, metacognitive, compensation, and affective strategies. More specifically, Rubin (1971: 21-23) mentioned seven characteristics of good language learners which reflected the learners' strategies:

(1) they are good guessers;

(2) they have strong drive to communicate and learn from a communication;

(3) they are often not inhibited;

(4) they are prepared to attend to form: constantly they are looking for patterns in the language;

(5) they practice the language;

(6) they monitor their own and the speech of others; and

(7) they attend to meaning: they pay attention not only to grammar of the language or to the surface form of speech, but also to the message.

Moreover, these learners' strategies will also depend on various factors. Schumann (1978:164) developed taxonomy of factors that influenced second language acquisition. He mentioned nine general factors: (1) social; (2) affective; (3) personality; (4) cognitive; (5) biological; (6) aptitude; (7) personal; (8) input; and (9) instructional factors.

In this study, the above theories will be used in the analysis of the data. Gina and Nadia's interlanguage will be considered as a certain stage of a language development, and the errors they made during this stage will be analyzed according to the above paradigm set by Selinker. Some of the above language learning strategies which are relevant to this study will also be discussed briefly.

\section{Method}

In gathering the language data, two different ways of collecting the data had been done: the observations and the analysis of some collections of the subjects' (school/home) work. Observations were done at the subjects' 
house and at the playground, a total of seven times. The observations were firstly intended to record the language used by the subjects (and their friends) in a natural situation. A microcassette recorder "Sony" model M-330 was used and put in my pocket so that the subjects did not know that they were being recorded. The conversations were then transcribed immediately after each observation. Secondly, these observations were aimed to study the subjects' learning strategies and factors related to the strategies. Another source for this data was additional information concerning the subjects' daily lives and their activities from their own parents.

Some of the subjects' school work and homework collections (work sheets) were also used as the data of this study. By asking permission from both the subjects and their parents, I borrowed those collections and then photocopied them.

The data are then analyzed and discussed. The procedure of error analysis spelled out by Corder (1974) is used to analyze the data. The procedure is as follows:

(1) a corpus of language is selected;

(2) the errors in the corpus are identified;

(3) the errors are classified;

(4) the errors are explained; and

(5) the errors are evaluated (Ellis, 1985: 51-2).

\section{The Subjects and Their Backgrounds}

The subjects of this study are two Indonesian children who came from an educated, middle class family. Their father, a Javanese pursuing his graduate program in Economics at Ohio University, is an instructor in one of the best Universities in Indonesia. Their mother, a Palembangese and a college graduate also in Economics, is a successful businesswoman in their hometown. Because money is not real problem, they often spent a lot of it on books and even a computer. They also sent their children to a special English class. They paid a great deal of attention to the education of their two daughters. So, it is not surprising when they said that Gina and Nadia are the best among their classmates: they are bright children.

Javanese is the most dominant language of the two children and the family. Indonesian is used in speaking to non-Javanese speakers and English to their classmates at East Elementary School at Athens, Ohio, and at "Sunday School" - a program held by the Muslim Students Association (MSA), Athens, where they learn to read Arabic, particularly the Qur'an.

These advantages - their parents were well-to-do and well-educated and also the subjects' experiences in learning languages other than their own mother tongue - will presumably influence their language learning strategies.

\section{The Results}

\subsection{Gina and Nadia's Language Learning Strategies}

The observations revealed that the subjects' language learning strategies were:

(1) they tried to communicate in English with their friends, teachers, and "foreigners";

(2) they used some Indonesian loan words in their conversations and pronounced them like English. Sometimes, they translated Indonesian into English;

(3) they were not inhibited;

(4) they practiced their English; and

(5) they were well-motivated.

Even though the two children had to spend almost eight hours a day at school (in Indonesia Gina spent five hours a day and Nadia three hours), they said that they liked their new school more than the one in their own country. Here, they said, they had a lot of friends from various countries and they were eager to communicate with them. They even hated some of their friends who did not want to speak to them. They said they were not afraid of talking in English with their friends because they felt that they could say what they wanted to say. The result of this positive attitude was obvious: Nadia got two certificates stating that her performance after only a month at school was excellent. 
In addition to their very good adjustment to a new situation and their eagerness to communicate, they were also good guessers. They used some Indonesian loan words (e.g. radio, kaset "cassette", pensil "pencil", pena "pen", etc.) in their speech and then tried to anglicize their pronunciations (/'redio/ not /radio/, /'k set/ not /kaset/, /'pitza/ not /pisa/, and even their names /'jina/ not /gina/, and /'nedia/ not /nadia/). In using negative sentences, first of all the used no for Indonesia bukan, and not for tidak, e.g. in I'm not like it for Saya tidak suka ini (but not *Saya bukan suka ini); and It's no mine for Ini bukan milikku (but not *Ini tidak milikku), but later they learnt to say I don't like it. It's yours; it's not mine ... as a chunk.

Moreover, they were also fearless risk-taker learners. Their mother said that, in one of the international women's meetings, they could talk to adults and asked many things eagerly. They would also do anything spontaneously if they were asked to do so. And when Gina's teacher asked her to copy a short story from a book as homework, her father reported, Gina thought it was a very easy job. What she did instead was: she read the story and then summarized it using her own words. Her teacher then asked her father whether he helped with his daughter's homework. He said that he was too busy to do that. Or maybe her mother? He said that Gina's English was much better than her mom's. She indeed did the homework by herself.

They often practiced their English while they were playing with their friends. I once watched them dancing with their friends while they were singing a song about Abraham Lincoln. They practiced their pronunciations by reading aloud and reading a poem. Nadia, their parents reported, was a good poetry reader when she was in her hometown. A very interesting way of how they practiced their English was role-playing: Gina acted as a teacher and Nadia with their friends as her students. Gina tried hard to imitate what had ever been said by her teacher. In this role playing, they learnt the expressions like let's see, stop it and good work ("managerial talk?") as a chunk and pronounced them as /let si/, stopit/, and /gudwək/.

Finally, they were very well motivated. When one day we went to Alden Library (the main library at Ohio University) and took the two girls to the special collections for children, they seemed very happy and spent almost two hours reading and looking for the books they liked. They asked if they could borrow those books and brought the home. They said that they wanted to read all of the books because they have to be able to speak fluently as soon as possible (I do not know whether they could see the application of reading to speaking; however, Gina said that by reading a lot of books, she could "know everything" so that when their friends talked about a certain topic, she could talk and not just keep silent). Sure enough, they are right: topics, vocabulary, and style are all affected. When we went home, I let Gina borrow seven books and Nadia eight.

In short, Gina and Nadia were good learners. They were gregarious and eager to communicate; they reacted positively to the people and got little negative feedback from their teachers and the environment (most of their work sheets were left uncorrected); they had positive attitude toward school and made a lot of friends; they were good guessers and fearless risk takers; they practiced their English; and they were integratively motivated.

\subsection{Gina and Nadia's Interlanguage}

Even though the children's English was getting better from day to day and they had more opportunity to practice their English, they actually faced difficulties in constructing a sentence particularly in using the copulative verbs, articles, prepositions, adjective-noun orders, negations, and interrogations.

However, pronunciation and spelling were not major problems for the two girls. When I came to their house to make my first observation on the girls' English - it was on a Martin Luther King Birthday holiday: a week after they had their first day at school - I wondered how Gina could produce interdental fricative sounds quite well when she was pronouncing the words LuTHer and birTHday. Those sounds are of course "new" to her because they do not "exist" in her languages. Nadia, on the other hand, was also able to identify the differences between English and Indonesian /r/. She said that her teacher had taught her how to pronounce that sound; and she was so confident in demonstrating those differences to me. She added that her teacher had also taught her all of the English alphabet and asked her to memorize and practice it thoroughly. It seems to me that the two girls had successfully learnt some basic English sounds.

Spelling was also not a big problem. Although sometimes they spelled words incorrectly - partially phonetic, partially visual memory - e.g. com for come in com here green bug; shcool for school, etc., Gina always got a perfect score on spelling tests. On the other hand, nadia - her teacher reported to her father - was the best speller in her class.

In constructing a sentence, they still had problems in inserting a copulative verb between subject and predicate and in using an appropriate word for the predicate of the sentence. This is particularly because their 
native languages do not have copulas. However, they made progress greatly. Nadia's telegraphic sentences (e.g. Dad ... here ..., Mom ... go ... e .. Kroger ...) had changed into full sentences (He's here; she went to Kroger) in about a month. Nadia could also say a longer sentence (e.g. I'm sorry, we have to go ..., You like pizza?) without any hesitation.

Gina's problems seemed more complicated because she is "smarter" and more cognitively advanced than Nadia, but perhaps not as "natural" because of older age. When she said "You like this?", "I'm not like pizza", it was understood that she still used Indonesian structures and "filled" them with English words. This structure was exactly similar to Indonesian sentence structure Kamu suka ini: you = kamu, like = suka, and this = ini; and in Saya tidak suka pizza: I'm = saya, not = tidak, like = suka, and pizza = pizza. Her real problems of transferring Indonesian structure into her English can be seen in the following work sheet:

Mr Pine making the signs

Is this some old signs, said Mayor

$\mathrm{Mr}$ Pine finished making the signs

Mr Pine go to the sleep

Said Mr Pine where's my glasses?

In the morning Mr Pine go to the street

Mr Pine making new signs

The people is protest to Mr Pine

Mr Pine to looking for glasses

$\mathrm{Oh}$, this is my glasses, Mr Pine glasses on the dog.

Or in this composition:

There was a little bird

The egg near the flower

The momy egg come to egg and

the mother sit down on the egg

The momy look the flower.

It is obvious that Gina had missed the linking/copulative verbs which are again because of the absence of them in her native language (e.g. in Mr Pine (...) making the signs; the egg (...) near the flower). Along with this problem, she could not also use the appropriate tense (e.g. in Mr Pine go to the sleep; the momy egg come to the egg). In sentence is this some old signs, Gina used copula is rather than are because her native language does not recognize a plural marker for determiner this. In Indonesian, she could say Ini tanda-tanda lama? and determiner ini can be translated either into this or these (The plural marker in Indonesian is on reduplication, in this case tanda-tanda, not on the determiner). And, finally, Gina used Indonesian structure in Said Mr Pine where's my glasses? by transferring her Indonesian Kata Pak Pine di mana kacamata saya? which was exactly the same structure. However, I can say that errors made by Gina were due not only to her native language interference but also to developmental errors - e.g. in Is this some old signs? Said Mr Pine where's my glases? (interference) and in Mr Pine making the signs; the egg near the flower (developmental) (see also Ellis, 1985; Corder, 1978).

However, from 59 sentences produced by Gina in this study, only 18 sentences can be categorized as sentences with missing copulative verbs.

In constructing negations, Gina also got some problems. Consider the following conversation:

Erica: Is this your book?

Gina: No, it's no mine. I ...

Because Indonesian has two different words for negation (tidak and bukan) and Gina had used "not" for "tidak" in I am not like pizza (Saya tidak suka pizza, but not *Saya bukan suka pizza), so she decided to use "not" for "tidak" "no" for "bukan". English's "It's not mine" is syntactically identical to Indonesian's "Ini 
bukan milikku" but not "* Ini tidak milikku". However, Gina was not consistent with her choice. The following was an example of her inconsistency:

Momy no look the flower because

the baby no came to mother.

If she had decided that "tidak" equivalent to "not" and "bukan" to "no", had to produce "momy not look ..." and "the baby not came ..." because that sentence can be translated into Ibu tidak melihat bunga but not *Ibu bukan melihat bunga. Gina made four wrong negations from nine sentences she produced for this study.

Meanwhile, in constructing questions Gina got less problems and she knew the rule: question words had to be put in the initial position of the sentences, such as in this dialog:

Ericka: Let's go

Gina: Where you go?

Ericka: Let's play outside.

Gina: Where you want go?

Ericka: Come on

or in her letter to me:

To uncle Yusuf

Happy Valentine's day

How are you? you fine

I am fine and my family

How are aunt Yusuf?

What did you have? an animal?

See you letter

Bye

Your child friend,

Gina

Kiss me please

In Indonesian, she could put the question words anywhere: Kemana kamu pergi (Where you go), Pergi kemana kamu (go where you), or Kamu pergi kemana (you go where). Similarly, Gina consistently said "Where you want go" although she could also construct these variations: You want go where "Kamu mau pergi kemana" or Want go where you "Mau pergi kemana kamu" but she put the question words in front of the sentences. In her spontaneous letter to me, it took her only a few minutes to do that - she produced those questions with ease and even those short questions: You fine? (even though she missed the copula) and an animal?

Gina made three incomplete interrogative sentences from a total of eight sentences she produced.

Other problems faced by Gina were the use of articles, prepositions and particles, and adjective-noun order. From 42 sentences she made, seven of them were without article (e.g. This is king family; I'm not king on the sun). This is particularly because in her native language this category does not exist. In using prepositions and particles, Gina used eight inappropriate prepositions from 21 sentences she made. This is presumably because she tried to translate them from Indonesian (e.g. go in the bath is a word for word translation from Indonesian pergi ke dalam kamar mandi "to go to the inside of the bathroom"). In constructing an adjective-noun order, she got four errors out of 15 sentences she produced. This is again because of her native language interference, e.g., Keluarga orang-salju was translated into family snowman (family "keluarga", snowman "orang-salju") in This is family snowman. 
The following chart summarized the language problems faced by Gina.

\begin{tabular}{|c|c|c|c|c|c|}
\hline No. & Aspects of Grammar & $\begin{array}{l}\text { Sentences } \\
\text { produced }\end{array}$ & Errors & $\%$ & Examples \\
\hline 1. & Copulative verbs & 59 & 18 & 35 & $\begin{array}{l}\text { The egg near the flower } \\
\text { The momy egg came to egg } \\
\text { Mr Pine making the signs } \\
\text { Mr Pine glasses on the dog }\end{array}$ \\
\hline 2. & Negation & 9 & 4 & 44 & $\begin{array}{l}\text { Momy no look the flower } \\
\text { The baby no came to mother } \\
\text { It's no mine }\end{array}$ \\
\hline 3. & Questions & 8 & 3 & 37.5 & $\begin{array}{l}\text { How are aunt Yusuf? } \\
\text { Where you go? } \\
\text { Where you want go? }\end{array}$ \\
\hline 4. & Articles & 42 & 7 & 16.7 & $\begin{array}{l}\text { This is King family } \\
\text { I'm not King on the sun }\end{array}$ \\
\hline 5. & Preposition particles & 21 & 8 & 38 & $\begin{array}{l}\text { I'm in the tree and jump go in the bath } \\
\text { The baby came out in the egg }\end{array}$ \\
\hline 6. & Adjective-Noun orders & 15 & 4 & 26.7 & $\begin{array}{l}\text { This is family snowman } \\
\text { This is draw my family } \\
\text { Your child friend }\end{array}$ \\
\hline
\end{tabular}

\section{Conclusion}

Gina and Nadia were good English learners: they had what Rubin (1979: 17-26) called "three variables" of good language learning: aptitude, motivation, and opportunity. They were bright children and they knew how to use their knowledge in learning a "new" language; they were good guessers and fearless risk takers. They were also integratively motivated: they practiced their English; they were gregarious and eager to communicate; they had positive attitude toward school and made a lot of friends, and reacted positively to the people and their environment. And finally they had now a good opportunity to learn English in its natural setting.

Even though they made systematic errors in constructing sentences, it can be said that those syntactical errors made by Gina and Nadia are due not only to their native language interference (e.g. I am not like pizza or it's no mine), but also to developmental errors (e.g. Nadia's Dad here, Mom go Kroger, or Gina's Where you (want) go, Mr Pine making the signs). Because this observation to see the subjects' language development was conducted in less than two months, it was understood that a process called "progressive restructuring" (Corder, 1978) - a process of adjustment into the target language - might have been occurring on the girls' acquisition of English.

The main implication of this study is on the teaching of English to the Indonesian speakers, either children or adults. It is obvious that the differences between English and Indonesian sentence structures have created difficulties to the learners. A teaching syllabus based on contrastive analysis will be more realistic and will "touch" the learners' language-leaning needs.

\section{References}

Corder, S. P. (1978). Language-learner language. In J. C. Richards (Ed.), Understanding second language acquisition and foreign language learning: issue and approaches (pp. 71-93). Rowley, Mass.: Newbury House.

Ellis, Rod. (1985). Understanding second language acquisition. Oxford: Oxford University Press.

Griffiths, Carol, \& Judy, M. Parr. (2001). Language Learning Strategies: Theory and Perception. ELT Journal, 55(3). Oxford: Oxford University Press. 
Grundy, P. (1999). From model to muddle. ELT Journal, 53(1), 54-55. Oxford: Oxford University Press. http://dx.doi.org/10.1093/elt/53.1.54

Lee, Chien Kuo. (2010). An Overview of Language Learning Strategies. ARECLS, 7, 132-152.

Macaro, E. (2001). Learning strategies: in foreign and second language classroom. London: Continuum.

Oxford, R. (1990). Language learning strategies: What every teacher should know. New York: Newbury House.

Oxford, R. L. (2003). Relationships between second language learning strategies and proficiency in the context of learner autonomy and self-regulation. Canarian Journal of English Studies, 38, 109-126.

Rubin, Joan. (1979). What the "good language learner" can teach us. In J. B. Pride (Ed.), Sociolinguistics aspect of language learning and teaching (pp. 17-26). Oxford: Oxford University Press.

Schumann, John, H. (1978). Social and psychological factors in second language acquisition. In J. C. Richards (Ed.), Understanding second and foreign language learning (pp. 163-177). Rowley, Mass.: Newbury.

Selinker, Larry. (1992). Rediscovering interlanguage. London: Longman Group Limited. 